\title{
PLANNING OF URBAN FORESTS IN RIGA AND MAJOR EUROPEAN CITIES
}

\author{
*Ieva Kraukle, Ilze Stokmane, Kristine Vugule \\ Latvia University of Life Sciences and Technologies, Latvia \\ *Corresponding author's email: ieva.kraukle@hotmail.lv
}

\begin{abstract}
With the increase in the number of the global population, that is likely to grow also in the nearest decades, the expansion of cities continues at the expense of forests and farmlands, and in these new areas, a more significant role is granted to the interaction between cities and countryside, revealing diverse interests of stakeholders. It is necessary to preserve, and it is even desirable, to expand the green spaces of the urbanized territories. Vienna, Stockholm, Copenhagen and Riga were selected for the study. The authors looked at the experience of the urban and green area planning through the literature review of city planning documents. Analyses of results show that planning takes place at the city, suburban or regional level and in the case of Riga, its development is similar to the development of other large European cities. The share of the urban forests in the territory of Riga city and its suburbs is comparatively large. In the European cities, which are rich in forests, the territories of the urban forests are often owned by local municipalities, and the development axes are created along highways, separating the diverse green territories. The authors offer a schematic model of the urban forest and urban area development for Riga city, which will ensure the preservation of forest areas and the non-confluence of urban areas.
\end{abstract}

Key words: urban forests, green belt, 5 Fingers Plan, urban development, social functions.

\section{Introduction}

During the last 100 years, global and radical changes have been occurring in society, and a large share of committed rural people has become typical city or town inhabitants. The processes of urbanization cause a lot of challenges and issues (the merging of urbanized territories, decrease of the areas of green spaces and their quality, and their fragmentation) revealed in the interaction of cities and their peripheries (Carreiro et al., 2008). The resilience of the cities is argued due to the socio-political consequences, climate change and also COVID-19 pandemics. Nature-based solutions are more frequently considered to be sustainable (Bayulken et al., 2021). The density of many built -up areas is increased, but not expanded at the expense of the green spaces. In the green territories of cities and their suburbs, alongside with environment protection, the social function has become one of the most vital functions diminishing the role of commercial wood production. The dominance of the social function of forests is critical, particularly under the Covid-19 conditions; and not only specialists are aware of the values of the forest, but also a wider community is developing awareness of the values of nature and the significant role of forest management.

The impact of COVID-19 has disclosed how critical for the wellbeing of people are the urban forest territories located on the outskirts, and, under the emergency situations, they are in a much higher demand than ever before. The recreation areas in urban forests are extremely significant. Taking into account the latest experience of the virus prevention in the nature park Ogres Zilie kalni gained by I.Kraukle working as a park director, the development of disperse recreation zones that limit the concentration of visitors, is particularly important.

In terms of spatial planning, comprehensive and integrated planning of the city and its periphery shall be addressed (Akmar et al., 2011; Hawkins \& Selman, 2002). Intensive balancing and satisfaction of needs is vital that can be achieved via a modern approach for spatial planning: an integrated evaluation of environmental, economic and social aspects (for instance, transport planning, use of sustainable resources, pollution reduction, landscape planning, taking into account the interests of the community (Konijnendijk et al., 2006). In the $21^{\text {st }}$ century, the structure of the 'City Fabric' has become looser resulting in less used areas within the city of Riga. However, zones of intensive urbanization are appearing in Pieriga that is located very close to Riga. Diverse phenomena such as economic, social and physical links, housing, employment and recreation are functioning beyond the administrative borders of Riga and Pieriga. The current experience of Latvia shows that, contrary to the experience obtained by other European countries (Akmar et al., 2011; Carreiro et al., 2008), too little attention has been paid to the planning of urban forests.

The urban forest is a natural or partly natural, or artificial ecosystem in all its stages of development. It is dominated by trees, the height of which in a particular location and time can reach at least $7 \mathrm{~m}$ and the projection of its current or potential canopy is at least $20 \%$ of the area covered by a forest stand (Meža likums, 20000. In the urban forest, the main functions are the social and environmental ones. The urban forest serves as a public outer space in an administrative environment and the urban territory beyond it.

A high number of residents are concentrated in a small territory adjacent to Riga. In the past, we could talk about urban forests within the territory of Riga and suburban forests in the periphery of Riga. The 
urban forests near the living areas were used mainly for walking and cycling on workdays, but suburban forests for recreation on weekends, reaching the forests by cars or public transport.

The urban forests are a constituent component of the multi-functional urbanized territories that improve life environment in the city. Forests are sustainable and self-sufficient structures on condition that people do not interfere with their natural processes. In the city environment, people exert their impact on it even without intensive cutting of trees, but they do that through their constant presence, recreation activities, and emission gases from cars, heating equipment and production facilities (Straupe et al., 2012).

Due to the changes and dispersion in the structure of the populated areas and due to the increase of the number of vehicles used by people, differences between urban and suburban forests have been decreasing. The populated areas have stretched into the suburban forest zones and are accessible via a 15 minute walk. The same 15 minutes are sufficient to reach a suburban forest on the outskirts of Riga by car (Jankovska, 2013). Because differences between the use of urban and suburban forests are decreasing, suburban forests require an equal approach to their planning and management, and they can be considered as urban forests (Jankovska, 2013).

The aim of this study is to analyse the systems of the urban forests in, Vienna, Stockholm, Copenhagen and Riga, which extend to the settlement structures of the cities as 'green fingers' or 'wedges', or separate the city settlement areas that tend to expand and merge and to offer a model for Development of Urban Forest Areas in Riga, on the basis of the international experience The 'green wedges' of urban forests is a mode of planning with the aim to limit the continuous expansion of urban areas that do not leave space for natural areas that are necessary for maintaining the environmental diversity and provision of services for forest ecosystems.

\section{Materials and Methods}

Territories in Vienna, Stockholm, Copenhagen and Riga have been chosen for the analysis of these capital cities with their nearest development zones, including the existing or purposefully developed green areas that restrict the merging of the urban areas. The selected cities are similar to Riga with many of the city forests, other green and water areas. Similar urban and suburban development is taking place in the areas, preserving green areas of different scales, with an emphasis on urban forests.

The available planning documents (Wieshofer et al., 2015; Stockholm, 1999; Stockholm City Plan 2018; Stahle, 2002) (and others described more detailed for each city below) characterizing the urban forest areas, were analysed as well as the city planning documentation and public mapping materials on the green areas in the above mentioned cities have been evaluated and compared. In the study, planning documents from 1990s until present days are reviewed.

\section{Results and Discussion}

\section{The Urban Forests in Vienna, Their Planning and} Governance

The green areas cover almost half of the territory of Vienna, including a vast range of green structures from small neighbourhood parks and green areas along the streets and in the yards, and trees and alleys to major historical parks, nature protection areas and urban forests near the city border (Erhart, 2002). In 1950s, the territory of Vienna was expanded by attaching large forest areas to it. The purpose of the city politicians was to keep the green belt around the area with the erected buildings, and new and large parks were constructed (Erhart, 2002).

The forests owned by the city of Vienna are being managed by the Office of Forestry and Agriculture. Specific management plans are developed for all these areas. Since 1960, more than 500 ha of forests have been planted for recreational purposes (Weidinger, 2011).

In the City of Vienna, the planning tool is the Law on the Industry of Building, the Community Development Plan and the legally binding Land Use Plan that are combined into one document (Wieshofer et al., 2015).

Informal planning documents that are not authorized by law are: the City Development Plan 94 (Stadtentwicklungsplan 94, STEP 94), the Plan Greenbelt Vienna 1995 and the Plan for Strategic Development of Vienna. The City Development Plan 94 sets the framework for the development of a planned land-use, and it prescribes 11 development axes for the city development, and between these axes large green areas are planned that shall be preserved and united in a network of green structures (Wieshofer et al., 2015). The Vienna Green Belt Plan 1995 demonstrates the network of green areas that shall create a belt around the built-up areas (Erhart, 2002).

It was followed by STEP 05 developed since 2005 , and it included the mission statement 'The Green Spaces of the Urban Region' aimed at Development for Sustainability. Pursuant to the mission, landscapes are constituent components for the development of the economic region and they form a foundation for protection of long-term high quality standard of living within the city region (Wieshofer et al., 2015).

The purpose of the mission statement "Green Spaces of the Urban Region" is to protect and develop landscapes, and to establish the settlement border of the city territory. The STEP 05 mission statement 
"Green Spaces of the Urban Region" remains the same regarding its principles for STEP 2025) (Wieshofer et al., 2015).

When drawing parallels with the case of Riga (described below) and its region, a conclusion can be made that both cities have comparatively large areas of urban forests with all functions typical of urban forests, and these functions are supported by the forest areas, and these spaces are managed by a municipal forestry organization. The planning situation is also similar, as no unified planning authority for the city and its region has been established neither in Vienna nor in Riga. Thus, high quality planning and the use of green spaces and urban forests for community needs are hampered.

Urban Forests in Stockholm and the System of the Green Areas

With the aim to find similarities in the Stockholm case and the Riga case regarding their population number, characteristics of the climate and plant species, this study has characterized the green structure of the capital city of Sweden, Stockholm.

The green structure covers $1 / 3$ of the territory of the city, $60 \%$ of the urban forests of Stockholm are owned by the municipality; thus, the use of these areas for the public recreation functions is enhanced.

Earlier, the Swedish urban forests were used mainly for production functions. In 1990s, the social values and functions of forests were identified, and new developments in the management of urban forests appeared. As Falck defines the urban forest, it includes all forests growing in the territory of the city and its suburbs. And he adds that the vegetation of land in urban forests is uncultivated (Rydberg \& Falck, 2000).

In the $30 \mathrm{~s}$ of the $20^{\text {th }}$ century, territorial planning in Stockholm was started, and radial development schemes with wedges of green spaces, separating the development areas, were drawn up. In the city development plan, fingers of intensive settlement were drawn along the highways keeping green wedges of non-urbanized areas between them not to allow merging of the urbanized areas. The green wedges have been developed up to now, and they are extending across the whole region forming easy accessible and usable green areas with high ecological value (Nordh \& Olafsson, 2020). As Figure 2 shows, the green structure of Stockholm comprises the natural habitat, green wedges, recreation areas and green connections.

In 1998, the mapping of degraded areas was initiated. In 1999, the mapping of the city of Stockholm under the title 'Build the City Inwards' (Stockholm, 1999) was started with the aim to develop the city without its expansion at the expense of the green spaces and urban forests particularly, but through an intensive use of the degraded or rarely used city areas (Stockholm 1999). In the Stockholm City Plan
2018, an increased city density was also stated as a possibility for development (Stockholm City Plan 2018).

In 2001, the City Council approved the first regional development plan for the Greater Stockholm (Nelson, 2009). The regional plan included two main objectives: to form regional development centres and to maintain the green structure and values of the territory within the city and outside of it. The major priority of the Stockholm Plan was to combine and preserve two functions of the green areas: recreation and preservation of biological diversity.

Stockholm has created the Green Map as a planning tool, consisting of three parts: the map of biotopes, the map of reuse of resources, and the map of socio-topes (Xiu et al., 2017) based on the concept of socio-topes that has been introduced into planning (created in 2004 and 2005). The maps of socio-topes are used for planning at the level of boroughs, and they focus on the qualities of urban forests and other green spaces, and on their development. At present, maps of socio-topes have been created not only in Stockholm, but also in Uppsala, Malmo, Gothenburg (Xiu et al., 2017).

Contrary to the concept of 'biotope' (ecologically defined environment), the socio-tope has been defined as a homogeneous place (topos) of a particular culture, community or group of individuals (socio) regarding the objectives for the use of that particular place, its social meaning and values. Pursuant to this concept, questions: 'For whom?', 'For what purpose?' and 'Where?' are put (Stahle, 2006).

In the urban environment, the urban forest should be available at the distance of $1 \mathrm{~km}$, providing swimming, fishing, skating and skiing possibilities, cultural-and-historical objects, broad views, waters; or a nature reservation with the area of more than 50 ha (Nelson, 2009; Ståhle, 2010).

The most important requirement for the urban forest is to have a sufficient area in order to meet the needs of the inhabitants of the city and suburbs, to preserve the environment and to provide comfort for people. The objective of the city of Stockholm is to have dense green structures of high quality for the achieving of which the following major strategies are described in the Park Programme (Stahle, 2002):

- Expansion of the green zones,

- Diversity of activities and elements,

- Concentration- renovation of the territories of the existing open spaces, enhancing their quality and accessibility,

- Management for maintaining well-functioning structures.

The map of the socio-tope and the guidelines of the Park Programme have been used for several city planning projects, and based upon them, the maps of 
socio-topes and the concept of green wedges have been created in other cities (Uppsala, Malmo, Gothenburg and Helsinki). For the planning and management of the green territories of Riga and other cities and towns of Latvia, it is recommended to use the Stockholm experience for the evaluation of the quantity of the green territories and for enhancing their qualities, taking into account the interests of individuals and community. The Green Structure of Copenhagen Urban Forests

The Green Network Plan was first drawn up in Copenhagen in 1936. A comprehensive recreation network plan was developed that included a system of nature parks connected in the north and northwest of Copenhagen. The Plan marked territories with highly valuable landscapes and the connecting corridors as greenways and ecological corridors, and the main landscape management principles for them were developed after several decades (Vejre, Primdahl, \& Brandt, 2007).

The origin of the regional structure of the Copenhagen 5 Fingers Plan dates back to the 1940s (Cahasan \& Clark, 2005). At the end of the 1960s, due to rapid development, the green wedges in several locations had turned into narrow lines, however, in the beginning of the 1970s, the planning and legislative instruments stopped the destroying of the green territories and reduction of areas (Vejre, Primdahl, \& Brandt, 2007). The green infrastructure planning at a municipal level is influenced by the national rules and guidelines as well as regional plans (Nordh \& Olafsson, 2020).

The 5 Fingers Plan includes several basic principles that contribute to the integration of new green elements into the existing structures of the city and its suburbs (Cahasan \& Clark, 2005):

- The urban environment is developed into narrow zones-fingers,

- The undeveloped green wedges are retained between the development fingers,

- The development of the fingers occurs along the public transport zones (with a focus on railroads),

- The peripheral urban areas are developed as individual elements of the common structure (as 'individual pearls in a bead'),

- The population shall reside close to the green spaces.

H. Verje states that, in general, the new landscapes can be characterized as modern gardens, forest recreational landscapes with some pasture and arable soil remains (Vejre et al., 2007). The functionality of the landscape has also changed respectively: the primary function is recreation, followed by the function of the nature biotopes for providing ecosystem services, then housing functions follow and, to a limited extent, production functions do.
The latest versions of the icon of the 5 Fingers Plan encourage us to reconsider also the situation in the Greater Riga where some parallels can be drawn with the green structures of Stockholm, Copenhagen and Vienna and their green structures in the peripheries.

\section{Characterization of Urban Forests in Riga}

In the opinion of the architect Arnolds Lamze, revealed in the General Plans of Riga back in 1924 and 1936, the plan shall be developed for a larger economic region (Lamze, 1932). The urban forests in Riga and the Greater Riga have been retained and expanded due to the intentional afforestation of dunes. Until the 1980s, for the purpose of restricting erosion caused by winds, mainly pines (Pinus silvestris) were planted, and their plantations were supplemented by grasses, willows (Salix), sea buckthorn (Hippophae) and other shrub species (Mangalis, 2004). Preservation of the forests was also fostered by the Soviet normative enactments, strictly limiting production activities in urban and periurban forests with the aim to create the 'green shield', as well as to keep timber resources that could be available easily and quickly in case of military conflicts.

The lifestyle area of the urban environment of Riga and its periphery that includes the shared 'urban fabric' of the City municipality and the neighbourhood municipalities, and the green territories create a unified structure that is not limited by any administrative borders.

The scheme of the settlement areas and forest wedges has been included in the map, schematically specifying densely populated, larger and smaller spaces, and the urban forest in Riga and its periphery. Thus, a focus is on the urbanized territories, which extend from Riga to the suburbs of Riga along the main road axes, showing the scattered urban forests in the periphery of Riga, as well as the dense wedges which are stretching from the green way of Riga.

Having generalized the scheme of the settlement areas in Riga and the forest wedges, the authors of this article offer a model for the territories of the urban forests in Riga and its periphery. In the scheme of the urban forests and green territories of Riga, the authors have found some similarity with the 5 Fingers Model of the Greater Copenhagen, and even five coastal extensions of settlement are present in this scheme.

As Figure 1 shows, the Riga Model includes radial extensions of the settlement areas, elements of the circle of the urban forests supplemented and connected with forest wedges structures.

Having compared the above model with the recommendations for the spatial planning of the Riga Planning Region, drawn up in 2007, the author I. Kraukle argues that the green wedges do not extend from Riga urban area, but, on the contrary, they extend into Riga from the large forests of the green belt, surrounding Riga. 


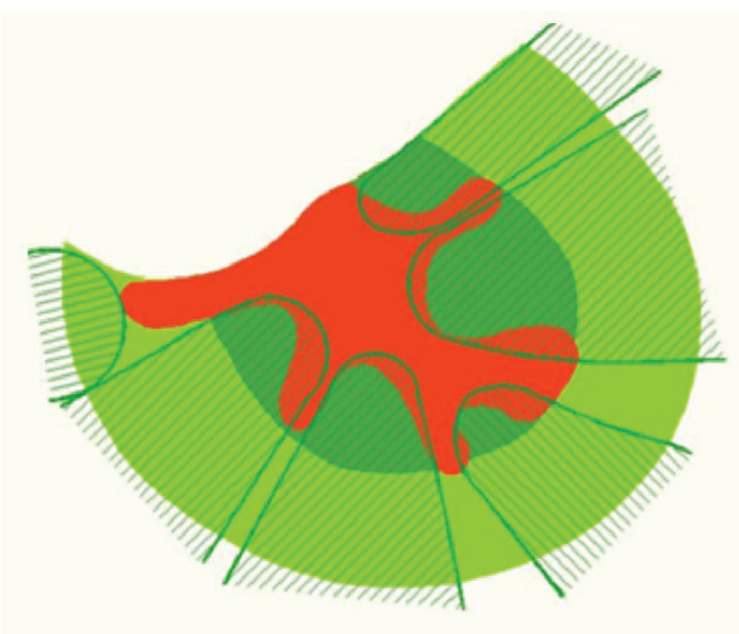

Legends:

Riga Urban area
Urban forests
Green belt
Forest wedges

Figure 4. Model of Territories of Urban Forests in Riga (Authors made, source Kraukle, 2013)

(Kraukle, 2013).

The scheme of the green network of Riga included in the Strategy for Sustainable Development of Riga City 2030 shall be supplemented. In spite of the fact that the outer green circle is outside of the border of Riga, the existing link between the forests of the green belt, which provide a higher vitality and effectiveness of the urban forests, is not depicted.

Kraukle reveals (Kraukle, 2013) the radial settlement extensions and the circle of the urban forests that separate these extensions and are actually created by the green zone forest wedges that sprawl to the Riga urban area.

The level of provision with amenities and facilities in the urban forests of the Riga urban area is still low, and insufficient attention is still paid to them. In many places, the only way how to protect the forest from the anthropogenic load is to update the existing amenities and facilities (Bell, 1997; Emsis, 1980). Also, measures for the soil re-cultivation/ tillage are critically necessary in many places in order to prevent soil erosion (Emsis \& Tuktens, 1988).

During the recent years, the municipalities of Riga and Pieriga have been creating recreation zones within the territories of the urban forests.

\section{Conclusions}

Viable forest territories, covering spaces with sufficiently large areas and tree stands of diverse structures and ages, and biological diversity shall be maintained not forgetting about amenities and facilities for recreation needs of the population. Diverse smaller structures (green corridors) that connect the urban forests and the largest parks shall be created and maintained. The green corridors are vital for the maintenance of biological diversity in the cases of excessive fragmentation of the green territories. The accessibility of the green territories via walking or driving 10-15 minutes becomes especially important.

As the analyses of the international experience shows, planning in European cities takes place simultaneously with the planning at the levels of the urban and suburban areas or regions. It is so in Copenhagen and Stockholm where the planning and governance of large green structures, including the urban forest territories, is implemented more successfully. All the examples, discussed above, refer to the territories around the country capitals. These particular territories of increased development include large green spaces, which are preserved in spite of the expansion of the urban areas.

In Vienna, the planning documents-are legally binding or informal. The informal planning documents include the plan of the Vienna Green Belt 1995 and the City Development Plans for a decade that-prescribe diverse activities in each stage for preservation and development of the green spaces.

Since 1998, in the plans of the City of Stockholm, the focus has been on the mission "Build the City Inwards" that emphasises the need to develop the city without any expansion of its territory, particularly preserving the green and urban forest areas and actively reusing the degraded and almost abandoned city territories. Stockholm has been using the Green Map as a planning tool since 2004 including information on biotopes, renewal of resources and socio-topes.

The Copenhagen Green Network Plan includes a system of interlinked nature parks, ensuring non-confluence of urban areas. The Copenhagen 5 Fingers Plan prescribes the development of the urban environment in narrow zones or fingers following the zones of public transport between which undeveloped green wedges are preserved ensuring that people have a possibility to live very close to the green spaces.

Planning documents in Riga do not strengthen and preserve the status of green territories enough. A territorial planning document in Riga is necessary in order to expand the status of the green territories not allowing their reduction. The Riga Model presented by authors will provide preservation of forest wedges, which will separate urban areas in Pieriga - Riga urban area. 


\section{References}

Akmar, A.A., Konijnendijk, C.C., Streetheran, M., \& Nilsson, K. (2011). Greenspace planning and management in Klang Valley, Peninsular Malaysia. Arboriculture \& Urban Forestry. 37(3), 99-107.

Bayulken, B., Huisingh, D., \& Fisher, P.M.J. (2021). How are nature based solutions helping in the greening of cities in the context of crises such as climate change and pandemics? A comprehensive review. Journal of Cleaner Production, Vol. 288, 1-20. DOI: 10.1016/j.jclepro.2020.125569.

Bell, S. (1997). Design for autdoor recreation. Spon Press.

Cahasan, P., \& Clark, A.F. (2005). Copenhagen, Denmark 5 fingers Plan. Retrieved October 15, 2020, from http://depts.washington.edu/open2100/Resources/1_OpenSpaceSystems/Open_Space_Systems/ copenhagen.pdf.

Carreiro, M.M. (2008). Introduction: The Growth of Cities and Urban Forestry. In: Carreiro M.M., Song Y.C., Wu J. (eds) Ecology, Planning, and Management of Urban Forests. New York, USA: Springer. DOI: 10.1007/978-0-387-71425-7 1 .

Emsis, I. (1980). Rīgas pilsētas meži un to apsaimniekošana (Riga City forests and their management). Riga:LatZTIZPI. (in Latvian).

Emsis, I., \& Tuktens, J. (1988). Atpūtas mežu labiekārtošana un atveseļošana (Improvement and recovery of recreational forests). Riga: LatZTIZPI. (in Latvian).

Erhart, E. (2002). The Greenstructure of Vienna - Case Study Vienna. Werquin, A.C., Duhem, B. [etc.] European Commission COST Action C11, eds. Final report 1-12. Forestry \& Urban Greening, No. 5, 195-201.

Hawkins, V., \& Selman, P. (2002). Landscape scale planning: Exploring alternative land use scenarios. Landscape and Urban Planning. 60(4), 211-224. DOI: 10.1016/S0169-2046(02)00056-7

Jankovska, I. (2013). R̄̄gas pilsētas mežu apsaimniekošanas problemātika un risinājumi (Challenges and solutions for the forest management of Riga City). Doctoral dissertation. Latvia University of Agriculture, Jelgava, Latvia. (in Latvian).

Konijnendijk, C.C., Ricard, R.M., Kenney, A., \& Randrup, T.B. (2006). Defining urban forestry - A comparative perspective of North America and Europe. Urban Forestry and Urban Greening, 4(3-4), 93-103. DOI: 10.1016/j.ufug.2005.11.003.

Kraukle, I. (2013). Pilsētmežu plānošana un pārvaldība: Lielrīgas piemērs (Urban forest planning and management: Greater Riga example). Master thesis. University of Latvia, Riga, Latvia. (in Latvian).

Lamze, A. (1932). Teritorijas problèma Lielrīgas izbūvē (Area problem in the construction of Greater Riga). Riga: Latvju kultūras spiestuve. (in Latvian.)

Mangalis, I. (2004). Meža atjaunošana un ieaudzēšana (Restocking and regrowing the forest). Riga: Et Cetera. (in Latvian.)

Meža likums (Forest law). (2000). Latvija Republikas Saeima. (in Latvian).

Nelson, A. (2009). Stockholm case study. City of Water. Retrieved October 26, 2020, from https://depts. washington.edu/open2100/Resources/1_OpenSpaceSystems/Open_Space_Systems/Stockholm_Case_ Study.pdf.

Nordh, H., \& Olafsson, A.S. (2020). Plans for urban green infrastructure in Scandinavia. Journal of Environmental Planning and Management, O(0), 1-22. DOI: 10.1080/09640568.2020.1787960

Rydberg, D., \& Falck, J. (2000). Urban forestry in Sweden from a silvicultural perspective: A review. Landscape and Urban Planning, 47, 1-18. DOI: 10.1016/S0169-2046(99)00068-7.

Ståhle, A. (2006). Sociotope mapping - exploring public open space and its multiple use values in urban and landscape planning practice. Nordic journal of architectural research, 19, (4), 59-71.

Ståhle, A. (2010). More green space in a denser city: Critical relations between user experience and urban form. Urban Design International, 15(1), 47-67. DOI: 10.1057/udi.2009.27.

Stockholm. (1999). Stockholm City Plan. Retrieved October 26, 2020, from http://miljobarometern.stockholm. se/content/docs/gc/10/Planning Strategies City of Stockholm2.pdf.

Stockholm City Plan 2018. (2018). Retrieved October 26, 2020, from https://vaxer.stockholm/globalassets/ tema/oversiktplan-ny_light/english_stockholm_city_plan.pdf.

Straupe, I., Jankovska, I., Rusina, S., \& Donis, J. (2012). The impact of recreational pressure on urban pine forest vegetation in Riga city, Latvia. 6(4), Issue 4, Vol. 6.

Vejre, H., Primdahl, J., \& Brandt, J. (2007). The Copenhagen Finger Plan. Keeping a green space structure by a simple planning metaphor. In Europe's living landscapes. Essays on exploring our identity in the countryside. (pp. 311-328). KNNV Publiching.

Weidinger, H. (2011). The Municipal Departament 49 serves for the social benefit of the people. In conference Sharing experiences on urban and peri-urban forestry. Unpublished. Brussels, Belgium. 
Wieshofer, I., Prochazka, E., Knoll, T., \& Cseny, A. (2015). Green and Open Spaces STEP 2025. Retrieved January 11, 2021, from https://www.wien.gv.at/stadtentwicklung/studien/pdf/b008440.pdf.

Xiu, N., Ignatieva, M., van den Bosch, C.K., Chai, Y., Wang, F., Cui, T., \& Yang, F. (2017). A socio-ecological perspective of urban green networks: the Stockholm case. Urban Ecosystems, 20(4), 729-742. DOI: $10.1007 / \mathrm{s} 11252-017-0648-3$ 